\title{
Die reëls en tussen die reëls van die Korintiërbriewe: Walter Schmithals se 'Die Gnosis in Korinth'
}

\author{
PB Boshoff \\ Vereeniging
}

\begin{abstract}
The lines and between the lines of the letters to the Corintians: Walter Schmithals' 'Gnosticism in Corinth'

The concern of this article is to represent Walter Schmithals' understanding of the Pauline letters to Corinth from his perspective of Paul's lively dialogue with gnostic opponents. It is done under the following headings: Introduction; Literary analysis; Opponents; Christology; Gnosticism; Anthropology; Ethics; Eschatology; Ecclesiology; Paul and the historical Jesus.
\end{abstract}

\section{INLEIDING}

Schmithals het in 1948/49 Bultmann se lesings oor 1 en 2 Korintiërs bygewoon. Hierdie lesings het by Schmithals 'n belangstelling gewek in die Korintiërbriewe en die Gnostiek wat daarmee saamgaan. Schmithals vertel dat hy later aan Bultmann die titel vir sy proefskrif voorgestel het as 'Die Gnosis in Korinth'. Bultmann het hierop gevra of dit nie te eng sou wees vir 'n proefskrif nie en voorgestel dat die titel eerder 'Die Gnosis im Neuen Testament' gemaak moes word. Schmithals het hierop ja geantwoord, maar hom tog voorgeneem om by sy oorspronklike titel te bly. Schmithals het meer as enigiemand anders erns gemaak met die Gnostiek as verklaringsagtergrond vir die verstaan van die Korintiërbriewe.

In sy verslag oor die proefskrif skryf Bultmann dat Schmithals se werk van 'n ongewone krag tot selfstandige denke getuig. Bultmann het dikwels met spanning gelees aan die duidelike uiteensetting en streng gedagtegang. 'Im Blick auf die Energie und Originalität des Denkens und die Konsequenz der Gedankenführung könnte man versucht sein, sie geradezu als glänzend zu bezeichnen' (Bultmann 1954).

Hoewel Bultmann nie met alle besonderhede kon saamstem nie, het die eindresultaat hom oortuig. 'Das Ergebnis der Arbeit halte ich für richtig' 
(Bultmann 1954). Baie tekste kom in 'n nuwe lig te staan en vrae wat voorheen nie beantwoord kon word nie, kry nou antwoorde. As predikaat vir die werk stel Bultmann magna cum laude voor. Die Gnosis in Korinth het drie drukke in Duits beleef. In 1971 is dit ook in Engels uitgegee.

\section{LITERERE ANALISE}

Schmithals (1984: 19-20) maak die gevolgtrekking dat 1 en 2 Korintiërs 'n lewendige diskussie tussen Paulus en die gemeente in Korinte reflekteer. 1 en 2 Korintiërs is die versameling van wesenlike gedeeltes van die dertien briewe wat Paulus, oor 'n periode van ses tot agt maande, aan die gemeente geskryf het. Schmithals probeer om die oorspronklike korrespondensie te rekonstrueer. Hierdie rekonstruksie sluit 'n literêr-kritiese analise van die briewe en 'n voorstelling van die verloop van gebeure in.

Die leidrade wat Schmithals volg in sy herrangskikking van die briewe, is die twee temas van polemiek teen dwaalleer en Paulus se apologie van sy apostelamp. Waar hierdie temas afwesig is of swak aanwesig is, dui dit op vroeë korrespondensie, want waar Paulus aan die begin kon gedink het dat hy met terugvalle na die heidendom toe te kampe het, word dit later duidelik dat hy met 'n spesifieke dwaalleer te doen het. Wanneer Paulus dan reageer op die vernuwings en verandering in die kultus en die leer, het die dwaalleraars nie daarop geantwoord nie, maar behendig tot die aanval oorgegaan deur Paulus se apostelskap te betwis (Schmithals 1984: 21-85). Schmithals laat die korrespondensie begin met 1 Korintiërs 11: 2:

Ek vind dit prysenswaardig dat julle in alles aan my bly dink en vashou aan die oorgelwerde leer soos ek dit aan julle oorgedra het.

Paulus besef hier nog nie dat die spanning in die gemeente deur dwaalleraars veroorsaak is nie en oordeel verdraagsaam en opbouend daaroor: want daar moet trouens spanninge onder julle wees sodat dit bekend kan word wie onder julle tot die dwaalleraars behoor' ( 1 Kor 11:19). Die eerste aanduiding van dwaalleraars in die gemeente vind Schmithals (1984: 28) in 1 Korintiërs 15: 12:

Maar as daar verkondig word dat Christus uit die dood opgewek is, hoe kom dit dan dat sommige onder julle beweer dat daar geen opstanding van die dooies is nie? 
In die daaropvolgende brief waarvan 1 Korintiërs 12: 1-3 'n deel uitmaak, word dit duidelik dat die dwaalleraars in Korinte pneumatici, dit wil sê gnostici, is. Want dit is hulle wat kan sê: 'Vervloek is Jesus' (Schmithals 1984: 34).

Die dwaalleraars gaan tot die aanval oor sodat Paulus in sy volgende brief moet antwoord op die beskuldiging dat hy nie 'wysheid' aan die Korintiërs verkondig nie (Schmithals 1984: 48):

Christus het my immers nie gestuur om te doop nie maar om die evangelie te verkondig, en dit nie met wysheidsredevoering nie, sodat die kruis van Christus nie sy krag verloor nie' (1 Kor 1: 17).

Een brief later wy Paulus sy hele volgende skrywe aan sy persoonlike apologetiek en hy begin met (Schmithals 1984: 57):

1 Elkeen moet ons as dienaars van Christus en bestuurders van die goddelike geheimenisse aansien. 2 Hierby word verder van 'n bestuurder verwag dat hy betroubaar moet wees. 3 Vir my mak dit nie in die minste saak nie dat ek deur julle of deur 'n menslike regbank beoordeel word nie; ek spreek ook self geen oordeel oor my uit nie (1 Kor 4: 1-3).

In sy laaste brief, die sogenaamde vreugdebrief, kan Palus met vreugde melding maak dat die gemeente getrou gebly het aan hom en aan wat hy hulle geleer het (Schmithals 1984: 79):

12 Ek het nie aan julle geskrywe as gevolg van iemand wat onreg gepleeg het nie, ook nie as gevolg van iemand wat onreg gely het nie, maar om aan die lig te bring, hoe ywerig julle julle vir ons voor Gods aangesig bemoei. 13 Daarom is ons nou heeltemal getroos ( 2 Kor 7 12-13a)

\section{DIE TEENSTANDERS}

Uit die aanval wat die dwaalleraars op Paulus se apostelskap maak, kan mens verwag dat hulle vir hulself die amp van apostel wou reserveer. En Paulus verwys ook daarna as hy hulle in 2 Korintiërs 11: 5 'danige apostels' noem. Hulle het ook soos Paulus gereis om sendingwerk te doen en het ook'n nuwe boodskap gehad om in die Christelike gemeentes te verkondig. Hulle het ook nie onderhoud van die 
gemeentes ontvang of verwag nie (Schmithals 1969: 108). Uit 2 Korintiërs 11: 22 ('Is hulle Hebreeërs? Ek ook. Is hulle Israeliete? Ek ook. Stam hulle van Abraham af? Ek ook') lei Schmithals (1969: 107) af dat hierdie apostels van Joodse afkoms was. Die kombinasie van apostels met 'n Joodse afkoms laat Schmithals (1969: 32) hulle leersisteem beskryf as 'n voor-Christelike Joodse Gnostiek. Die aanrakingspunt met die kerklike verkondiging was 'Christus'. Christus is vanuit die Joodse tradisie oorgeneem en gepneumatiseer in 'n Christus-gnosis.

\section{CHRISTOLOGIE}

Vir Schmithals (1969: 117-122) was die uitleg van 1 Korintiërs 12: 1-3 'n deurbraak in die bepaling van wie Paulus se teenstanders in Korinte was en hoe hulle teologie daaruit gesien het. Die Korintiërs het by Paulus navraag gedoen oor die pneumatici, die geestesmense, in hulle midde, wat 'n skerp onderskeid gemaak het tussen 'Christus na die gees' en 'Christus na die vlees'. Paulus en die gemeente het ook hierdie onderskeid geken tussen die aardse verskyning van Christus en Christus wat die Here is. Maar hierdie onderskeid het hulle nie as 'n skeiding verstaan nie; die gekruisigde Jesus is ook die opgestane Here Jesus. Die pneumatici in Korinte het egter verder gegaan en uitgeroep: 'Vervloek is Jesus'. Die gemeente was nie seker of dit toelaatbaar is nie en op hulle navraag antwoord Paulus:

1 Wat die pneumatici betref, broers, wil ek julle nie onkundig laat nie. 2 Julle weet dat, toe julle heidene was, julle na die afgode, die stommes, meegevoer is, soos julle ook al gelei is. 3 Daarom wys ek julle daarop dat niemand deur die Gees van God praat en sê: 'Vervloek is Jesus' nie en niemand kan sê: 'Jesus is Here' nie, behalwe deur die Heilige Gees.

Die pneumatici noem Jesus 'n vervloeking in die gemeentelike byeenkoms, en tog is die gemeente nie seker of so 'n vervloeking nie met die belydenis van Christus te versoen is nie. Uit die gemeente se onsekerheid moet die afleiding gemaak word dat daar ' $n$ Christelike rigting was waarin dit moontlik was om die Christus te bely en tegelyk Jesus 'n vervloeking te noem. Watter Christelike rigting kan so 'n paradoks huisves? Wie kan in die Christelike erediens uitroep: 'Vervloek is Jesus!'?

Vir die beantwoording van hierdie vraag verwys Schmithals na die dwaalleer waarteen 1 Johannes gerig is, waarin ontken word dat Jesus die Christus is (1 Joh 2: 22). 'n Jood kan ook ontken dat Jesus die Christus is. Maar in hierdie geval word 
nie ontken dat die Messias al gekom het nie, soos wat Jode dit doen nie. Hier word ontken dat Jesus in die vlees gekom het:

Hieraan ken julle die Gees van God: elkeen wat bely dat Jesus werklik die Christus is wat mens geword het, het die Gees wat van God afkomstig is (1 Joh 4: 2).

Die dwaalleraars ontken die menswording van die Christus. Hulle aanvaar dat Hy deur die water gekom het, maar ontken dat Christus 'deur water en bloed' gekom het (1 Joh 5: 6). 'Bloed' moet ons hier lees as die werklikheid van die liggaam, die mens Jesus. Hierdie dwaling is deur die gnostici versprei. Hulle het aanvaar dat die hemelse Christus Homself by die waterdoop in die Jordaan getoon het en woning gemaak het in die liggaamlike Jesus, maar sonder om Homself aan die vlees te bind. Christus bly die Verlosser wat van bo kom en nie werklik deel word van die mens Jesus nie.

Schmithals (1969: 120) verklaar dat dieselfde soort gnostici waarteen 1 Johannes polemiseer ook in Korinte aan die werk was. Hulle kon in die erediens in ekstase uitroep dat Jesus vervloek is. Hulle het as Christene deurgegaan omdat hulle die hemelse Christus bely het, maar ontken dat $\mathrm{Hy}$ mens geword het, 'deur bloed' gekom het. En hierdie ontkenning het hulle skerp uitgedruk met 'Vervloek is Jesus!'.

Schmithals beklemtoon dat die Korintiese gemeente, soos Paulus, ook onderskei het tussen Christus na die vlees en Christus na die gees. So 'n onderskeid is in hulle onderlinge gesprekke gemaak. Onder Christus na die vlees moet ons die aardse verskyning van die Verlosser, van wie ons baie min weet, verstaan. Die Verlosser het die vlees aangeneem; Hy het mens geword. Christus het deur bloed gekom. Onder Christus na die gees moet ons die hemelse Verlosser in onderskeid tot die aardse gestalte wat Hy inneem, verstaan. Christus het deur water gekom.

Die gnostici in Korinte kon egter nie aanvaar dat daar eenheid en kontinuïteit tussen Christus na die vlees en Christus na die gees is nie; dat $\mathbf{H y}$ deur water en bloed gekom het nie. Hulle het aanstoot geneem aan die menslikheid van die mens Jesus. Hierdie aanstoot het hulle in ekstatiese vervoering laat uitroep: 'Vervloek is Jesus!'. Die vervloeking het nie vir die hemelse Christus gegeld nie, maar hiermee wou hulle ontken dat die aardse verskyning, die bloed, die kruis, die vernedering van die Verlosser enige betekenis het. Hierdie ontkenning van die betekenis van die kruis gaan verder as wat vir die gemeente aanvaarbaar is en daarom doen hulle navraag. 


\section{GNOSIS}

Met 'n opvallende wending grens Paulus hom in 1 Korintiërs 1: 17 van sy opponente af:

Want Christus het my nie gestuur om te doop nie, maar om die evangelie te verkondig, nie in wyse betoog nie, sodat die kruis van Christus nie verydel word nie.

Paulus polemiseer teen die 'wyse betoog'. Schmithals (1969: 134) maak die afleiding dat Paulus onder die 'wyse betoog' nie bloot die logiese en kunstige betoog van die wysheid verstaan nie, maar dat dit ook oor die inhoud van die wysheid self gaan. Die inhoud van hulle wysheid kom daarop neer dat hulle, volgens Paulus, die kruis van Christus verydel. In 1 Korintiërs 2: 1 kombineer Paulus die vorm en inhoud van die wysheid waarteen hy dit het, as hy skryf dat hy nie 'gekom het met hoogklinkende woorde of wysheid' nie.

Vorm en inhoud gaan saam en bepaal mekaar wedersyds. Van sy eie styl sê Paulus dat hy 'in swakheid en in vrees en in groot bewing' (1 Kor 2: 3) na die Korintiërs gegaan het. Schmithals (1982: 72) meen dat ons by hierdie woorde nie moet dink aan 'n fisies of psigies aantoonbare siddering en bewing van die apostel nie. Dit gaan wesenlik daarom dat Paulus nie met 'n groot gejuig die gekruisigde kom verkondig het nie, omdat die sondige mens in die aangesig van die gekruisigde Christus, in wie God Hom openbaar, sy eie onmag ervaar. Menslike onmag is die keersy van die heil wat van God af kom. Die vorm waarin Paulus verkondig, 'nie met 'n omhaal van woorde nie', pas by die inhoud wat hy verkondig, Jesus Christus en Hom as gekruisigde.

Soos wat Paulus se styl pas by die inhoud van wat hy verkondig, pas die wyse betoog van sy bestryders by die inhoud van wat hulle verkondig. Die inhoud van die dwaalleer wat met hoë woorde verkondig word, dui Paulus aan as hy beklemtoon dat hy 'Jesus Christus en Hom as gekruisigde' verkondig. Die kruis was nie deel van die inhoud van die dwaalleer nie. Om hierdie dwaalleer nader te omskryf, hou Schmithals (1969: 134) vas aan die noue verbintenis tussen vorm en inhoud en maak die afleiding dat dit ' $n$ wysheid was wat in Korinte verkondig is. ' $n$ Wysheidsleer wat die kruis as inhoud nie het nie, is in Korinte gepropageer.

Die feit dat Paulus net in die vorige sin die krag van God teenoor mensewysheid gestel het en dan die toegewing maak dat hy nogtans 'n wysheid leer: 'wysheid leer ons onder die volmaaktes' (1 Kor 2: 6) regverdig die afleiding dat wysheid die saak onder bespreking was. Die dwaalleraars in Korinte het Paulus daarvan beskuldig dat dit wat hy verkondig, nie wysheid is nie (Schmithals 1969: 142-145). Teen 
hierdie beskuldiging verweer Paulus hom deur aanvanklik die toegewing te maak dat hy ook 'n wysheid leer onder volmaaktes en daarna tot die aanval oor te gaan: die wysheid wat hy ook te leer het, moes hy nog van die Korintiërs weerhou omdat hulle nie volmaaktes is nie. Die twis en tweedrag onder die Korintiërs (1 Kor 3: 3) is die bewys dat hulle nog nie ryp is vir wysheid nie.

Die inhoud van die wysheid wat Paulus ook nog te leer het, kan nie die woord van die kruis wees nie, want dit het hy juis nie van die Korintiërs weerhou nie. Dit was die hoofsaak wat hy aan hulle verkondig het: 'Ek het my voorgeneem om met julle oor niks anders te praat nie as oor Jesus Christus en Hom as gekruisigde' (1 Kor 2: 2). Vir hierdie geloofsbegrondende boodskap het Paulus niemand as onvatbaar beskou nie. Ter wille van die opbou van die gemeente keer Paulus telkens terug na hierdie eerste beginsel. Vir die volmaaktes het Paulus egter 'n wysheid te leer wat voortvloei uit hierdie grondboodskap en daarmee in ooreenstemming is, maar nie self die geloofstigtende woord is nie (Schmithals 1981: 76). Hoewel Paulus hier nie 'n voorbeeld gee van die wysheid vir die volmaaktes nie, het hy dit wel op ander plekke gedoen. Schmithals (1982: 76) noem byvoorbeeld 1 Korintiërs 15: 51:

Ek deel aan julle 'n geheim mee: Ons sal nie almal ontslaap nie; maar ons sal almal verander word.

Hierdie wysheid het gelowiges nie nodig om te ken nie, die volmaaktes mag dit ken, hoewel dit nie van wesenlike waarde is nie (Schmithals 1981: 78).

Afgesien van die wysheid wat die pseudo-apostels in Korinte verkondig en die wysheid wat Paulus vir die volmaaktes hou, sou hy sy eie boodskap ook 'n wysheid kon noem: 'die getuienis van God' (1 Kor 2: 1). Schmithals (1981: 71) verduidelik dat Paulus met hierdie woorde aan sy opponente wil sê dat die aanspraak wat hulle maak dat hulle wysheid die mens tot die werklike kennis van God kan lei, 'n ongegronde aanspraak is. Eers waar die gekruisigde Christus verkondig word, word die menslike bestaan ten volle voor God blootgelê. Die wysheid van Paulus se opponente gee voor dat dit die goddelike waarheid leer, maar hierdie waarheid bly verborge waar die gekruisigde Christus nie verkondig word nie. In belydenisstyl beklemtoon Paulus dat 'Jesus Christus vir ons deur God tot wysheid gemaak is, tot geregtigheid en tot heiliging en tot verlossing' (1 Kor 1: 30). Schmithals (1981: 70) meen dat Paulus in hierdie geval met opset 'wysheid' in die hoofposisie geplaas het en dit uitle deur wat daarop volg: geregtigheid, heiliging en verlossing. Wysheid word uitgelê deur begrippe wat elkeen in sy bepaalde konteks die omvattende heil uitdruk. Die drie begrippe kom ook byvoorbeeld voor in 1 
Korintiērs 6: 11 sonder 'wysheid': 'maar julle is afgewas, julle is geheilig, julle is geregverdig'. In 1 Korintiërs 1: 30 is Paulus dus daarin geïnteresseerd om wat dit wat hy verkondig, wysheid te noem en dit Christologies te fundeer.

Uit die feit dat Paulus sy boodskap wysheid noem en dit stel teenoor die wysheid van die pseudo-apostels, lei Schmithals (1981: 71) af dat hulle wysheid nie maar net die beoefende wetenskap van daardie tyd was nie, maar dat dit 'n omvattende sisteem moet gewees het. Paulus en sy teenstanders maak dieselfde aanspraak, naamlik om die omvattende waarheid te leer. Paulus fundeer die waarheid wat hy verkondig Christologies, wat inhou dat die mens nie oor hierdie waarheid beskik nie; dit kom van God af. Die wysheid van die pseudo-apostels is volgens Paulus 'n menslike wysheid waarin die mens op homself aangewese is, dit wil se heil as menslike moontlikheid.

Paulus gebruik die term oodia, wysheid, om daarmee sy opponente se leer te beskryf. Hierdie term was egter nie tuis in die Korintiese situasie nie, maar kom van buite. Sy oorsprong lê in die leerteks 1 Korintiërs 1: 18-31 (Schmithals 1981: 31). Hierdie Pauliniese homilie of leerteks is nie spesifiek vir die Korintiese situasie geskryf nie, maar vir daardie omstandighede aangehaal, met die byvoeging van vers 30, spesifiek vir die omstandighede in Korinte. Met die term ooфía wou Paulus die inhoud en vorm van die ketterse leer in Korinte tipeer (Schmithals 1969: 135). Die eintlike tegniese term wat in Korinte self gebruik is om die leersisteem te beskryf, is yvworc, kennis. Schmithals (1969: 134-135) vind 'n aanduiding hiervan in 1 Korintiërs 8: 1 waar Paulus woordeliks uit die navraag van die gemeente aanhaal: 'Ons almal het die kennis'. Hoewel dit in die konteks gaan oor die eet van vleis wat aan afgode geoffer is, word 'ons almal' gekarakteriseer as mense wat 'kennis' het. En in 1 Korintiërs 13: 8-13 kry Schmithals (1969: 135-136) steun vir sy aanname dat die

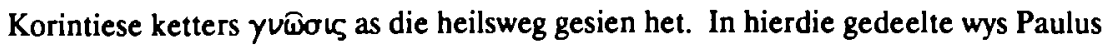
op die gebrekkige van die kennis en daarteenoor die volmaakte, blywende van geloof, hoop en liefde. Die mens se heil lê nie in die kennis nie, maar in vertroue op God. Ook in 1 Korintiërs 8: 1 word liefde teenoor kennis gestel: 'Kennis maak verwaand, maar liefde bou op'.

Vir die identifisering van Paulus se teenstanders in Korinte is 2 Korintiërs 11: 4-6 ook van groot belang:

4 Want as iemand na julle toe kom, wat 'n ander Jesus verkondig, wat ons nie verkondig het nie, en julle 'n vreemde Gees ontvang, wat julle nie ontvang het nie, en 'n vreemde evangelie, wat julle nie aangeneem het nie, dan verdra julle sulke mense met graagte. 5 Maar ek gaan daarvan uit dat ek in niks by hierdie opperapostels agterstaan nie. 
$6 \mathrm{Al}$ is ek nie so glad met die woord nie, in die kennis staan ek nie agter nie; daar is niks, wat ons nie aan julle openbaar het nie.

Schmithals (1969: 137) toon aan dat die yvworls, kennis, in vers 6 die hoofbegrip van die boodskap van die indringers in die gemeente is. Die begrip yvwow is deur die pseudo-apostels in Korinte gebruik en Paulus verantwoord hom in daardie situasie deur juis hierdie begrip op te neem.

\section{ANTROPOLOGIE}

Paulus gee self die aanleiding aan vir sy skrywe oor die opstanding: "hoe sê sommige onder julle dat daar nie 'n opstanding van die dooies is nie?' (1 Korintiërs 15: 12). Die apokaliptiese gebeure van die opstanding lê anderkant die bekende wêreld en anderkant menslike moontlikheid. En Schmithals (1969: 147) twyfel nie daaraan nie dat Paulus onder die indruk was dat die Korintiërs alle hoop op 'n transendente werklikheid verloën het. Sulke mense het net 'n leë hoop in Christus gestel (1 Korintiërs 15: 19). Vir hulle bly daar niks beters oor nie as om die teenswoordige te geniet met 'laat ons eet en drink, want môre sterf ons!'

Paulus was egter nie goed ingelig oor die opvattings van die Korintiërs nie, soos ook blyk uit 1 Korintiërs 15: 29:

Wat verwag diegene dan wat hulle vir die dooies laat doop? Waarom laat hulle hulle in elk geval vir die dooies doop, as die dooies nie opgewek word nie?

Die plaasvervangende doop vir 'n dooie maak nie sin uit nie as die dooies nie ook opstaan nie. En 'diegene wat hulle vir die dooies laat doop', is dieselfde groep gemeentelede as 'sommige wat sê dat daar nie 'n opstanding van die dooies is nie'. As dit nie dieselfde groep was nie, sou Paulus nie hulle gedrag so teen hulle opvattings kon afspeel nie (Schmithals 1969: 146).

Uit hierdie gegewens maak Schmithals (1969: 147) die afleiding dat die Korintiese groep die opstanding van die dooies bestry het, maar tog nie hulleself as sonder hoop sou beskou nie, omdat hulle 'n spiritualistiese transendensieverwagting gehad het. Die Gnostiek dring homself op as dit kom by die identifikasie van 'n groep met sulke opvattings omdat die verwerping van die opstanding van die liggaam vir die Gnostiek 'n grondliggende dogma was. Die liggaam was vir hulle die veragtelike kerker van die eintlike mens wat van die vlees bevry moet word. Die hoop van die opstanding van die liggaam het die gnostikus nie nodig nie, omdat hy 
reeds in besit is van sy heil (Schmithals 1969: 148-149).

In 2 Korintiërs 4: 7 gebruik Paulus die eienaardige beeld: 'Ons het hierdie skat in kleipotte'. Die skat is die apostel se kennis van die heerlikheid van God of die evangelie wat hy verkondig. Hierdie skat is in 'kleipotte' sodat die mense sal weet dat die krag van hierdie prediking nie uit die swak apostel self kom nie, maar van God. Die 'kleipotte' is die swak liggaam van die apostel. Die seldsaamheid van hierdie uitdrukking lê daarin dat die swak konkrete liggaam die houer is van die abstrakte kennis van die apostel. Schmithals (1969: 151) soek die oorsprong van hierdie uitdrukking in die polemiek wat die apostel teen die Gnostiek gevoer het. Die dualisme van vlees en gees was kenmerkend van die Gnostiek. Hulle het ook uit die swakheid van die liggaam, die breekbaarheid van die kleipot, sy ontoereikendheid en veragtelikheid afgelei. Vir hulle is die kleipot breekbaar, sodat die oortreffende krag van die pneuma of gees getoon kan word. Die Gnostiek verkondig die oortreffende krag van die menslike gees, die eintlike van die mens. Die menslike pneuma is hulle skat. Paulus neem formeel die dualisme van sy opponente oor, in die tweeheid van skat en kleipot is die liggaam die houer van wat hy glo en verkondig. Vir Paulus is die liggaam egter nie die veragtelike deel van die mens nie, maar die hele menslike bestaan. En die menslike swakheid is nie vir hom 'n rede om die menslike liggaam te verwerp nie; dit moet eerder behou word as 'n teken daarvan dat die mens aangewese is op goddelike genade. Die heil wat van buite die mens, van God af kom, is die krag wat alles oortref. Menslike swakheid en goddelike krag vul mekaar aan. In plaas van die gnostiese dualisme verkondig Paulus 'n spanningsvolle eenheid van die mens wat voor God mag lewe.

Schmithals se uitleg van 1 Korintiërs 15 waarvolgens die gnositci in Korinte die opstanding ontken, sluit dan goed aan by hulle verwerping van die menslike liggaam omdat hy so swak is, soos blyk uit 2 Korintiërs 4: 7. Die vlees is swak en verwerplik vir die gnostici.

Paulus se antidualistiese standpunt kom nie net in die genoemde tekste voor nie, ook 2 Korintiërs 12: 9 is 'n mooi voorbeeld daarvan:

Hy het my geantwoord: 'My genade is vir jou genoeg, want die krag word in swakheid volbring. Daarom sal ek liewer in die swakhede roem, sodat die krag van Christus by my woon. Daarom is ek bly oor swakhede, beledigings, ontberings, vervolging en moeilikhede ter wille van Christus, want as ek swak is, is ek sterk.

Paulus beklemtoon hier weer die liggaamlike swakheid. Schmithals (1969: 154) vind geen spoor daarvan dat Paulus se teenstanders 'n kwessie gemaak het van 'n fisiese 
swakheid van hom nie. Nêrens word sy siekte teen hom gehou nie en die pseudoapostels gee ook nêrens te kenne dat hulle op hulle fisiese krag staat maak nie.

As Paulus soveel klem gelê het op die liggaamlike van die mens, terwyl die indringers in die gemeente die liggaam verag, wat was dan vir hulle die eintlike wese van die menslike bestaan? Schmithals (1969: 160-161) vind 'n aanduiding van die antwoord op hierdie vraag in 1 Korintiërs 7: 40 waar Paulus moet verseker dat hy ook die Gees van God het: 'Maar ek meen dat ook ek die Gees van God het'. Paulus benadruk dat nie net hulle nie, maar ook hy die Gees het. Hieruit lei Schmithals af dat Paulus se opponente van hulself getuig het dat hulle die Gees van God het. En hoewel daar nie in hierdie enkele woorde 'n uitgebreide pneumatologie aangegee word nie, pas dit goed in by die gnostiese pneumaleer waarvolgens elke pneumatikus persoonlik rekenskap gee van die pneumadeel in hom. Paulus gee met sy woorde egter nie rekenskap van die pneumadeel in hom nie; vir hom is dit die goddelike geskenk aan 'n onwaardige mens wat hom vir sy amp as apostel toerus.

Wat 1 Korintiërs 12:1 betref, verskil eksegete onder mekaar of dit gelees moet word as 'aangaande die geestesgawes' of as 'aangaande die geestesmense'. Schmithals (1969: 161-162) kies vir die laasgenoemde lesing. Hierdie woorde identifiseer 'n groep geïnspireerde pneumatici in Korinte vir wie die besit van pneuma hulle van die ander onderskei het.

Paulus neutraliseer hierdie voorkeurposisie van die pneumatici wanneer hy in 1 Korintiërs 12:9 pertinent stel dat geloof ook 'n geestesgawe is (Schmithals 1969: 163). Geloof moet nie hier anders verstaan word as wat Paulus dit gewoonlik bedoel nie. As geloof ook 'n gawe van die Gees is, dan is alle gemeentelede in gelyke mate geïnspireerdes: dié wat verkondig en glo sowel as dié wat maar net glo. Die een Gees gee al die gawes en elke gawe is nuttig, nie net die pneumatici se gawes nie (Schmithals 1969: 162-163, 344).

Die gawe waarmee die pneumatici uitgeblink het, was die spreek in tale (Schmithals 1969: 164-165). Hierdie gawe was so belangrik omdat die pneuma alle ander geestelike funksies van die mens uitgeskakel het en die spreek in tale die bewys gelewer het van die pneuma wat aan die werk is. Die glossolalie het gedien as onweerspreekbare aanduiding van ekstatiese godsdienstigheid.

Schmithals (1969: 166-167) kry ook in 2 Korintiërs 10: 1-10 aanduidings van beskuldigings wat die indringers in Korinte teen Paulus gemaak het. Dit is gnostiese pneumatici wat sê dat hy 'gedweë' is as hy by hulle is en 'manhaftig' as hy van hulle af weg is; sy briewe is lesenswaardig en die moeite werd, maar sy optrede is flou en onopvallend. Wat Paulus se briewe vir die pneumatici aanneemlik en veelseggend maak, is dat daarin uitdrukkings voorkom soos 'Ek dank God dat ek meer ongewo- 
ne tale of klanke gebruik as julle almal' (1 Kor 14: 18). 'n Gedeelte wat ook in hulle kraam sou pas, is 1 Korintiërs 2: 6-3: 3. Nog 'n uitspraak waarmee die gnostici ingenome sou wees is volgens Schmithals (1969: 221) 1 Korintiërs 6: 19:

Of weet julle nie dat julle liggaam 'n tempel is van die Heilige Gees wat in julle is, wat julle van God het, en dat julle nie aan julleself behoort nie?

In hierdie gedeeltes word die apostel pneumatikus vir die pneumatici. Maar die indruk wat sy opmerkings gemaak het, het Paulus nie met sy optrede bevestig nie. In die praktyk het Paulus afgesien van ekstatiese bewyse van sy godsdienstigheid en daarom het hy op hulle die jammerlike en swak indruk gemaak. Sy verkondiging, terwyl hy by sy volle verstand was, was vir die gnostici ver benede die peil van wat hulle verwag het.

Besonder duidelik kom die Korintiese antropologie na vore tussen die reëls van 2 Korintiërs 4: 2-5 (Schmithals 1969: 173-174, 180):

2 Ons lê alle skandelike heimlikheid af, tree nie op met sluheid en misbruik nie die woord van God nie. Ons beveel onsself eerder aan deur die openbaring van die waarheid, aan elke menslike gewete voor God. 3 Maar as ons evangelie verborge is, dan vir die wat verlore gaan, 4 omdat die God van hierdie wêreldtyd hulle, die ongelowiges se verstand verblind het, so dat hulle die ligtende glans van die evangelie van Christus, wat God se ewebeeld is, nie sien nie. 5 Ons verkondig naamlik nie onsself nie, maar Christus Jesus as die Here; terwyl ons julle slawe is ter wille van Jesus.

Die gedeelte open met ' $n$ verweer van Paulus teen beskuldigings dat hy die evangelie finansieel misbruik. Paulus vervolg om homself as apostel aan te beveel, waarmee hy antwoord op die aanspraak van sy teenstanders in die gemeente dat hulle aanbevelingsbriewe kan toon (vgl 2 Kor 3: 1). Paulus se aanbeveling berus op die 'openbaring van die waarheid'. Schmithals verduidelik dat die uitdrukking 'openbaring van die waarheid' gerig is teen die pneumatici se uitdrukking 'openbaring van die gees' (1 Kor 12: 7). In vers 3 verdedig Paulus sy evangelie en die verborgenheid daarvan teenoor die gnostici se bekuldiging dat sy evangelie verborge is.

Die pneumatici het die pneuma in hulle verkondig. Die pneuma van die gnostikus is van nature goddelik en hy maak dit openbaar in die hoop dat die pneumatiese vonk op ander sal oorspring. Die goddelike pneuma gee onversteur- 
bare heilsekerheid aan sy besitter en geen verantwoordelikheid vir die toekoms word van hom verwag nie. In ekstase verlaat die pneuma-self van die mens sy veragtelike liggaam en bereik die toestand van volmaaktheid (Schmithals 1969: 169). Vir Paulus is die heil nie so vanselfsprekend en objektief as vir die Gnostiek nie. Die heil is eerder subjektief en afhanklik daarvan dat elke mens die boodskap van die apostel in sy eie gewete sal beproef. Paulus kan sy evangelie ook nie demonstreer in uiterlike ekstases nie, daarom gee hy toe dat dit verborge is. Maar hierdie verborgenheid geld net vir die ongelowiges, nie vir die gelowiges nie, wie se gewetens deur die boodskap oorreed word. Die boodskap het Christus as die volle goddelike waarheid as inhoud. So word Paulus diensbaar en verkondig hy nie homself nie, nie sy pneuma-self nie, maar vir Christus.

Vir die gnostikus was dit sy vanselfsprekende godsdienstige plig om op homself te roem en homself aan te beveel. Die pneuma moet algemeen bekend word. Vir Paulus is so ' $n$ roem en aanbeveling uitgesluit 'want nie hy wat homself aanbeveel is beproef nie, maar wie die Here aanbeveel' ( 2 Kor 10: 18; Schmithals 1969: 176).

In 2 Korintiêrs 13: 3 is Paulus weer besig om sy apostelskap te verdedig. Hy bevestig dat Christus in hom praat: 'aangesien julle 'n bewys soek van die-Christuswat-in-my-praat, wat teenoor julle glad nie swak is nie maar kragtig is onder julle'. Schmithals (1969: 183) bring die Christus-in-my in verband met die identifikasie van Christus en pneuma in 2 Korintiërs 3: 17 'die Here is die pneuma'. Volgens die gnostiese mite is die pneuma-self van die mens 'n deeltjie van die kosmiese Christus. In die oertyd het hierdie deeltjies 'n tuiste gevind in die liggame van die pneumatici. Hierdie Christus is besig om sy gevange deeltjies te bevry (Schmithals 1969: 185). Die Christus-wat-in-my-praat is dan die pneuma wat tot die besef kom van sy bevryding. Die ekstatiese spreek in tale lewer die bewys van die bevryding van die pneuma (Schmithals 1969: 183).

Die Christus-in-my is dieselfde, net uit ' $n$ ander hoek, as 'om van Christus te wees', wat in 2 Korintiërs 10: 7 voorkom: 'as iemand oortuig is dat hy 'van Christus is', dan kan hy terselfdertyd daaraan dink: soos hy self 'van Christus is, so ook ons'. In gnostiese taal beteken 'om van Christus te wees' dieselfde as om bewus te wees van die pneumadeel van Christus in jou. Vir Paulus beteken dieselfde uitdrukking egter net 'om 'n Christen te wees' (Schmithals 1969: 186-187).

Vanuit hierdie insig verklaar Schmithals dan ook die sogenaamde Christusparty in die gemeente van Korinte: 'Ek bedoel dit, dat elkeen van julle sê: 'ek behoort aan Paulus', of 'ek behoort aan Apollos', of 'ek behoort aan Sefas', of 'ek behoort aan Christus' (1 Kor 1: 12). Met hierdie woorde word nie vier partye bedoel nie. Die leidende beginsel in hierdie vers is dat die apostelgroep, Paulus, 
Apollos en Sefas, teenoor die Christusgroep gestel word. Die chiastiese kombinasie met die volgende vers laat Schmithals hierdie afleiding maak:

'ek is van Paulus', of 'ek is van Apollos', of 'ek is van Sefas', of 'ek is van Christus. Is Christus verdeel? Is Paulus vir julle gekruisig? Of is julle in die naam van Paulus gedoop (1 Kor 1: 12)?

Paulus laat die gemeentebouwerk wat hy en Apollos en Sefas gedoen het, 'n eenheidsfront vorm teen die gnostiese Christusgroep. Die evangelie wat deur mense verkondig word, staan teenoor die 'Christus-wat-in-my-praat' (Schmithals 1969: 188-191).

\section{ETIEK}

Met betrekking tot die eet van offervleis wat aan afgode toegewy is, meen die gemeente in Korinte dat hulle in hierdie opsig genoegsame kennis besit om daarvolgens te kan optree: 'Ons almal het die kennis' (1 Kor 8: 1). Wanneer hulle sê: 'ons almal het die kennis' dink hulle nie daaraan dat daar onder hulle ook sommiges kan wees wat nie die kennis het nie. En dit is tipies gnosties om geen beperking op die vryheid te plaas nie. Miskien sou eers Paulus se direkte weerspreking van hulle aanspraak dat almal die kennis het: 'Maar nie almal het die kennis nie' (1 Kor 8: 7) hulle oë daarvoor oopmaak dat daar ook swakkes onder hulle is. Die kennis gee nie uitdrukking aan 'n stand van sake nie, maar moet bewus bly van die noodsaak om die naaste in ag te neem en in die ontmoeting met hom bewaar bly. Schmithals (1969: 217) meen dat die meerderheid van die gemeente Paulus se standpunt aanvaar het, maar dat hulle beroep op die kennis na vorm en inhoud aanvanklik tipies gnosties is. Schmithals lei af dat die werklike gnostici in hierdie saak op die agtergrond staan. In 'n vorige skrywe kom hulle duideliker in die visier as Paulus teen afgodsdiens waarsku (1 Kor 10: 14-22). Hulle het aan kultiese maaltydvierings van afgode deelgeneem. Uit Paulus se argument word dit duidelik dat hy met mense redeneer wat moedswillig aan die heidense kultusmaaltye deelneem om daarmee te demonstreer dat die demone oorwin is. Hierdie houding is tipies gnosties (Schmithals 1969: 214). Die gnostici wil hulle krag toon met hierdie gebare en Paulus waarsku dat hulle nie hulleself as sterker as God moet beskou nie (1 Kor 10: 22). Die gemeente het hulle by Paulus aangesluit deur nie aan heidense kultusetes deel te neem nie, maar wil nou verder weet met betrekking tot die gewone, niekultiese eet van vleis wat aan afgode geoffer is (1 Kor 8: 1). 
Behalwe die motivering dat die gnostikus oor die demone heers en daarom van die offervleis mag eet, minag hy ook die liggaam so dat niks liggaamliks enige gevaar vir sy heil kan inhou nie. Die minagting van die liggaam en die onaantasbaarheid bo die demone kombineer ook vir die gnostiese praktyk van hoerery. In 1 Korintiërs 6: 12-20 waar Paulus hierdie saak behandel, begin hy ook met 'n slagspreuk van sy opponente: 'Alles is my geoorloof. Hierdie spreuk gee, net soos 'ons almal het die kennis', uitdrukking aan die gnostiese selfbewussyn dat die liggaam niks is nie en dat die pneumatikus mag oor die demone het (Schmithals 1969: 219).

In die merkwaardige gedeelte van 1 Korintiërs 6: $13-14$ word die eet van afgodsoffervleis met hoerery gekombineer:

13 Die voedsel is vir die maag en die maag vir die voedsel - maar God sal altwee tot niet maak. Die liggaam is nie vir hoerery nie, maar vir die Here, en die Here vir die liggaam. 14 God het die Here opgewek en sal ons ook deur sy krag opwek.

Die Korintiese gnostici het geleer dat mens alles mag eet en sonder wroeging op elke manier geslagtelike omgang kan beoefen, want die liggaam en die maag is verganklik. Later in 1 Korintiërs 10: 28-30 gaan Paulus grondig in op hierdie saak:

28 Maar as iemand uitdruklik vir julle sè: 'Hierdie is offervleis', moet dan nie daarvan eet nie, ter wille van hom wat dit gesê het en ter wille van die gewete. 29 Natuurlik bedoel ek nie die eie gewete nie, maar die van die naaste, want ' $n$ vreemde gewete kan nie oor my vryheid oordeel nie! 30 As ek met dank eet: hoe kan ek beskuldig word oor die kos waarvoor ek die tafelgebed uitgespreek het?

Paulus was egter op die stadium van 1 Korintiërs 6: 13-14 nog nie bewus van die gnostiese agtergrond en hulle saak oor die eet van offervleis nie, daarom gee hy hier nog toe op die punt. Maar wat die hoerery betref, kan hy nie daarmee saamgaan nie dat die liggaam verganklik is en daarom eties neutraal is nie. Hierteenoor stel hy dat die liggaam opgewek word, dus onverganklik is (Schmithals 1969: 220).

Schmithals verstaan 1 Korintiërs 7: 1-24 as Paulus se reaksie op die navraag van die gemeente wat min of meer soos volg moes gelui het: 'As die omgang met hoere verbode is, beteken dit dat ons ons ook in die huwelik van geslagsverkeer moet weerhou of die huwelik selfs moet ontbind en ongetroud moet bly?' In beginsel beaam Paulus die ongetroude staat en onthouding, maar in die praktyk is dit nie 
moontlik nie, omdat almal nie so 'n gawe het nie (Schmithals 1969: 222).

Die onbelangrike uiterlike van die sluier wat vrouens moet dra, kry ook betekenis vir die stryd tussen Paulus en die pneumatici. Die pneumatici het die afskaffing van die kopbedekking vir vrouens geëis omdat die geslagtelike verskil tussen man en vrou betekenisloos word wanneer die pneuma van die mens sy wesenlike uitmaak. Uit 1 Korintiërs 11:10 ('Daarom moet die vrou 'n teken van die man se gesag op haar kop dra ter wille van die engele') lei Schmithals af dat die kopbedekking verstaan is as ' $n$ afweermiddel teen demoniese engelmagte. Vir die pneumatikus wat oor die kennis beskik, bestaan daar egter geen rede meer om die bedekking te dra nie, want sy is veilig gestel bo die demoniese magte (Schmithals 1969: 229- 230).

Op sy beurt kan Paulus ook nie die noodsaak vir die dra van die sluier bewys nie. Na 'n teleurstellende poging beroep hy hom maar op die samewerking van die gemeente: 'Ons ken nie so 'n gewoonte nie' (1 Kor 11: 16). Schmithals verduidelik dat die dwang waarmee die pneumatici die sluier wou afskaf vir Paulus op sy hoede gestel het dat hier 'n ander evangelie verkondig word. Vir Paulus is die vryheid van die geloof verlore as die sluier nie meer gedra mag word nie. Hierdie vryheid moet in die konkrete beslissings gehandhaaf word (Schmithals 1969: 228-229). Dit gaan nie vir Paulus om grondliggende verskille tussen die geslagte nie. Die verskille is in die Here' opgehef. Paulus kan selfs in gnostiese terminologie verklaar: 'Nou is daar nie meer Jood en heiden, nie meer slaaf en vrye, nie meer man en vrou nie; want hulle almal is een in Christus' (Gal 3:28; Schmithals 1969: 226-227).

Nadat Paulus aanvanklik geen beswaar teen die optrede van vroue in die gemeente het nie (1 Kor 11: 2-16), beroep hy hom tog later (1 Kor 14: 34) op die tradisie om haar tot swye te bring. Schmithals lê dit so uit dat Paulus eers later besef het dat die gnostici op grond van hulle libertinistiese opvattings agiteer dat die vroue in die gemeente moet optree en dat hy dit wil afweer. Dit sal daarom 'n onPauliniese gebruik van Paulus wees om net eenvoudig te sê dat vroue in die gemeente moet swyg. Paulus het self nie die Christelike vryheid so verstaan nie (Schmithals 1969: 231-232).

\section{ESKATOLOGIE}

Vir die uitleg van die moeilike gedeelte van 2 Korintiërs 5: 1-10 wys Schmithals (1969: 247-248) daarop dat Paulus hier nie 'n uiteensetting gee van wat hy onder antropologie en eskatologie verstaan nie. Die eksegeet moet nie hier lees asof die apostel uit eie beweging vertel wat hy glo nie. Wat hy te sê het, word tot 'n groot mate deur die argumente van sy teenstanders voorgeskryf. Paulus begin met: 'Ons 
weet'. Dit wil sê, hy gryp terug na 'n leerstuk wat hy reeds in die gemeente behandel het. Hierdie ou stof het nou in die gedrang gekom en Paulus moet dit teen aanvalle verdedig.

Paulus was eers onder die indruk dat die pseudo-apostels in Korinte geleer het dat met die dood alles verby en verlore is, omdat hulle die opstanding ontken het. As daar geen opstanding is nie, kan daar ook nie 'n ewige lewe wees nie. Maar as hierdie die werklike standpunt in Korinte was, sou Paulus net nodig gehad het om hom te beroep op wat hy reeds in 1 Korintiërs 15 geskryf het. Paulus behandel egter in 2 Korintiërs 5: 1-10 die tema 'die ewige' op so 'n wyse dat dit tussen die reëls duidelik word dat sy opponente ook 'n 'ewige lewe' aanvaar, hoewel hulle die opstanding ontken.

Paulus se teenstanders het vir hulleself 'n ewige lewe voorsien waarin die ware mens losgemaak is van die woning van die liggaam en waarvoor die opstanding van die liggaam glad nie nodig is nie. Dit is nie nodig dat 'n hemelse woning reggemaak word nie, want die ewige lewe word liggaamloos deurgebring. Vir Paulus is die ewigheid sonder die kleed van 'n liggaam 'n teenstrydigheid wat hy in 2 Korintiërs 5: 3 ironies beskryf: 'Altans as ons in die ewigheid beklee en nie naak gevind word nie'. Die naaktheid van liggaamloosheid waarna die gnostici uitsien, beteken vir Paulus niks minder as die dood nie (Schmithals 1969: 251).

Paulus het nie die dualisme van die gnostici geken of verstaan nie. Hy het nie besef dat die ewige, soos die gnostici dit voorstel, voortvloei uit 'n hele sisteem nie. Hy het net hulle voorstelling van die ewige geïsoleerd met sy voorstelling daarvan vergelyk. Paulus het verlang om met 'n nuwe liggaamlikheid in die ewige lewe beklee te word en het dieselfde verlange by sy opponente veronderstel, maar hy moes verneem dat hulle 'n liggaamlose ewige lewe verwag. Vir hom was dit absurd om van 'n liggaamlose lewe te praat, want liggaamloos is dieselfde as die dood. Paulus toon hierdie absurditeit aan, maar praat verder verby sy opponente. Hy vind hulle nie omdat hy en hulle elkeen iets anders onder liggaamloosheid verstaan. Vir hulle is dit lewe, maar vir hom is dit die dood (Schmithals 1969: 251).

Paulus het wel besef dat sy opponente teologies argumenteer dat die swakheid van die liggaam enige liggaamlikheid uitsluit in die ewige lewe. Hierteenoor beklemtoon Paulus die kwaliteit en eienskappe van die nuwe liggaam: "n nie-methande-gemaakte ewige huis in die hemele' (2 Kor 5: 1). In ons 'aardse tentwoning' sug ons en verlang ons na die hemelse woning. Die benouende van die aardse woning is vir Paulus die bewys dat die verlange na die wydheid van die hemelse geregverdig is. Ons verlange is genoeg aanspraak om van die aardse bevry te word en in te trek in die hemelse woning (Schmithals 1969:250). 
Paulus moes eintlik bewys het dat 'n liggaamlose lewe, soos die gnostici dit voorstel, 'n onmoontlikheid is, as hy reg aan die werklike standpunt in Korinte wou laat geskied. Schmithals (1969: 252) meen dat Paulus nie hierop ingaan nie, omdat hy hom nie 'n liggaamlose bestaan kan voorstel nie en nie in staat is om van iets wat hy nie kan voorstel nie, die onmoontlikheid te bewys nie. Die onvoorstelbare liggaamlose lewe hoef nie nog ontken te word nie, want die onvoorstelbaarheid ontken dit klaar. Indien Paulus sou probeer om die onmoontlikheid van 'n lewe sonder liggaam te bewys, sou sy opponente hom van 'n gebrek aan gnosis beskuldig, dat hy as gevolg van onkunde nie so 'n voorstelling kan maak nie.

'n Verdere bewys dat Paulus onder dwang van die pseudo-apostels argumenteer, vind Schmithals (1969: 255-256) in vers 6: 'Ons weet: solank ons in die liggaam inwoon, woon ons ver van die Here af. Hier dink Paulus nie meer aan die hemelse liggaam wat die aardse liggaam, sonder ' $n$ tussenpose, verslind nie. Paulus het die gnostiese uitdrukkingswyse sy eie gemaak, waarvolgens die ware mens sy liggaam agterlaat om by die Here te wees. In hierdie terminologie beklemtoon Paulus teenoor die oorspanne versadigingsbewussyn van die gnostici die 'nog nie' van die eskatologiese voorbehoud. Ons leef nog in die verganklike liggaam, ver van die Here af. Die gnostici het hulleself gesien as mense wat net skynbaar in die liggaam lewe, in werklikheid lewe hulle reeds in die Here, in die kosmiese liggaam van Christus.

Schmithals (1969: 257-258) verduidelik dat Paulus nie voorgestel moet word as iemand wat onseker was oor die menslike liggaamlikheid nie. Paulus het nie twee standpunte daaroor gehad nie. Paulus se uitsprake moet teen die agtergrond van sy polemiek met die gnostici verstaan word. Aanvanklik, in 2 Korintiërs 5: 1- 5, rig Paulus hom teen die dualistiese verlange om van die liggaam ontslae te raak. Daarna, in vers $6-8$, rig hy hom teen hulle opgeblasenheid asof hulle reeds in Christus wandel. Paulus aanvaar sy opponente se uitgangspunt om nie van die begin af deur hulle verwerp te word nie. Hy kan dit doen omdat dit nou nie die uitgangspunt is van wat belangrik, soos in 2 Korintiërs 5: 1-5, is nie. Vanuit die gemeenskaplike uitgangspunt beveg Paulus dan die gnostiese hoogmoedigheid wat vir hom besonder ergerlik was.

In 2 Korintiërs 5: 9-10 gaan Paulus oor tot die toepassing van die voorafgaande. Hy rig hom teen die libertinisme van die Korintiërs. Selfs as hulle reeds by die Here is, moet hulle nog daarna streef om vir Hom aanneemlik te wees en vanselfsprekend geld dit ook vir die wat nog nie by die Here is nie. Almal moet voor die regterstoel van Christus verskyn. Schmithals (1969: 260) maak die opmerking dat hierdie opskerping van verantwoordelikheid in die aardse lewe by die gnostici op dowe ore geval het, omdat hulle nie meer rekening gehou het met 
die verskyning voor die regterstoel van Christus nie, want hulle was reeds 'in Christus'.

\section{EKKI ESIOLOGIE}

Schmithals (1969: 41-42) beskryf die struktuur van die voor-Christelike gnostiek in drie stappe: 'n hemelse wese (1) begewe hom in die materie (2) en beywer hom daar om weer na bo op te styg (3).

Elke mens of pneumatikus is betrokke in die stryd om van die materie los te

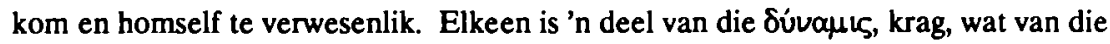
materie verlos moet word.

Van Simon die Towenaar se leermeester, Dositheus, wat homself as so 'n hemelse wese beskou het, word gesê, dat hy homself as 'Christus' voorgehou het. Simon wat 'Die groot krag van God' (Hand 8:10) genoem is, het ook van sy aanhangers die titel 'Christus' gekry. Hulle het die titel uit die Jodedom oorgeneem, maar het die Joodse inhoud daarvan laat vaar (Schmithals 1969: 41). Met 'Christus' beskryf hulle die hemelse ligwese of die gnostiese Oermens. Hy word nie een keer uit 'n vrou gebore nie, maar het reeds vroeër verskyn en ook later verskyn hy en hy ontstaan as een wat gebore is en nog gebore word. Christus is nie 'n bepaalde mens nie, maar is as 'dunamis' in baie mense te alle tye verdeel. Hy het hom in die materie begewe en moet weer vry kom. Christus verlig die kragdeeltjies wat slaap tot bevryding (Schmithals 1969: 45-46). Christus is ook reeds in die voorChristelike tydperk as pneuma geïdentifiseer (Schmithals 1969: 53).

Dit is teen die agtergrond van hierdie mitologies-gnostiese terminologie waarteen uitdrukkings soos 'Christus in ons' en 'ons in Christus' verstaan moet word. 'Christus in ons' beskryf die verdeling van die Christus in pneumadeeltjies, terwyl 'ons in Christus' weer die aandag vestig op die versameling van die verstrooide kragdeeltjies. Paulus beskryf egter met 'in Christus' en 'van Christus' bloot die gelowiges, sonder om aan die mitologiese voorstelling vas te hou (Schmithals 1969: 59-60).

Die hemelse Christus-Oermens is ook graag as 'n kosmiese liggaam voorgestel. Die ledemate van die liggaam word gebou uit die individuele pneumadeeltjies. Schmithals (1969: 60-61) wys op die merkwaardige formulering van Paulus: 'Want soos een liggaam baie lede het en die baie lede saam een liggaam bou, so is dit ook met Christus' (1 Kor 12: 12). Paulus skryf 'Christus' maar bedoel 'kerk'. Schmithals twyfel nie aan die gnostiese agtergrond van hierdie identifikasie van Christus en kerk nie. Paulus deel egter nie die gnostiese oortuigings nie, want 
volgens hom is mens nie van nature deel van hierdie liggaam nie, maar op grond van persoonlike gehoorsaamheid (Schmithals 1969: 62).

'n Vergelykbare gedeelte staan in Ef 4: 11-13:

11 En Hy het gegee sommige as apostels, ander as profete, ander as evangeliste, ander as herders en leraars 12 om die heiliges toe te rus, dat hulle hul diens doen en die liggaam van Christus opbou, 13 tot ons daarby kom, dat ons in die een geloof en in die een kennis van die Seun van God verenig is, tot volkome man word en die volle maat van die volheid van Christus bereik.

Schmithals (1969: 64) verstaan dit so, dat die volkome mens die Oermens is wat tot die volheid van sy verlossing gekom het. Hier word hy aan Christus gelyk gestel.

In 1 Korintiërs 10: 16b-17 haal Paulus, uit die gnostiese tradisie, 'n broodmaalwoord aan, wat sterk herinner aan die uitdrukkings 'ons in Christus' en 'Christus in ons':

16b Die brood, wat ons breek: beteken dit nie die gemeenskap met die liggaam van Christus nie? 17 Want soos wat dit een brood is, so is ons baie een liggaam; ons eet naamlik almal van die een brood.

Schmithals (1969: 234) is seker daarvan dat hierdie formule volgens die gnostiese opvattings beteken het dat die breek van die brood op die verdeling van die liggaam van Christus, die Oermens, dui. En dat die eenheid van die brood weer dui op een herkoms en bestemming van die pneumadeeltjies. Paulus het self nie die liggaam van Christus hier as die kerk verstaan nie, want in die vorige vers bring hy dit in verband met die bloed van Christus.

Hoewel hierdie broodmaalwoord uit die gnostiese wêreld kom, is die gebruik van sakramente wesenlik vreemd aan die Gnostiek. Liggaam en bloed is vir hulle die veragtelike materie en daarom kan 'n opregte gnostiese kultushandeling nie op liggaam en bloed gebaseer word nie. Dat daar tog 'n sakramentstradisie in die Gnostiek bestaan het, kan net verklaar word uit die feit dat die gnostici hulleself nie suiwer kon hou van die sinkretistiese tendense van daardie tyd nie (Schmithals 1969: 233-235).

In verband met die nagmaal beklemtoon Paulus dat hy die nagmaal so aan die gemeente oorgelewer het soos wat hy dit van die Here ontvang het. Dit het beteken dat die gemeente brood en wyn in liturgiese vorm geëet en gedrink het. 
Die brood kon waarskynlik meer gewees het as die stukkie wat ons vandag by die nagmaal kry, maar dit was nooit bedoel om 'n vullende maaltyd te wees nie. Die normale eet en drink moet elkeen by die huis doen (Schmithals 1969: 238).

Berigte uit die gemeente dui daarop dat daar in die gemeente 'n nuwe praktyk ontstaan het waarin die liturgiese maaltyd vervang word met 'n gewone maaltyd:

20 Wanneer julle almal met mekaar saamkom, dan gebeur dit naamlik nie, om die maaltyd van die Here te eet nie. 21 Elkeen eet eerder sy eie maaltyd gedurende die maaltyd, sodat die een honger bly en die ander hom dronk drink. 22 Het julle dan geen huise om daar te eet en drink nie? (1 Kor 11: 20-22).

Die bedoeling van die 'eie maaltyd' was om die 'maaltyd van die Here' oneer aan te doen en te profaniseer. Die nuwe maaltyd moes nie van 'n gewone maaltyd onderskei kon word nie (Schmithals 1969: 239-241).

So 'n verandering van die 'maaltyd van die Here' na 'n gewone maaltyd toe pas goed in in die gnostiese benadering. Hulle kon hulleself nie versoen met 'n kultiese maaltyd waarin die dood van die gekruisigde, vleeslike Jesus verkondig word nie. Hulle neem deel aan die nagmaal, maar op hulle eie manier, om waarskynlik daarmee hulle veragting vir die oorgelewerde tradisie uit te druk (Schmithals 1969: 241).

In 1 Korintiërs 15: 29 verwys Paulus na die plaasvervangende doop, waarvolgens iemand hom in die plek van 'n ongedoopte gestorwene laat doop. Hierdie praktyk is nooit in die kerk beoefen nie, maar wel in die Gnostiek wat dit uit die misteriekultusse oorgeneem het. Hierdie oorname is maklik te verklaar omdat die gnostikus hom moes bekommer het oor die mens wat sonder gnosis dood is. Deur die magiese daad van die doop vir die gestonwenes word die gebrek aan kennis aangevul en word hy van die demoniese magte bevry en die volheid ingelei. Schmithals wys daarop dat die doop volgens die gnostiese opvattings net ter wille van dooies ondergaan kon word, aangesien die gnosis vir die lewendes die verlossing is en die doop vir hulle niks meer as 'n beeld van die verlossing kan wees nie (Schmithals 1969: 245).

In die Korintiese gemeente was dit ' $n$ uitgemaakte saak dat die outoriteit van die apostel in die gemeentelike lewe noodsaaklik is. Maar daar is betwis dat Paulus op die apostelskap aanspraak het. Schmithals meen nie dat Paulus teen Apollos en Petrus afgespeel is nie. Dit is nie hulle vir wie Paulus spottend 'danige apostels' (2 Kor 11: 5; 12: 11) en waarskuwend 'valse apostels, bedrieglike werkers, wat hulle 
verklee as apostels van Christus (2 Kor 13) noem nie. Die opperapostels is die pneumatici self wat deur hulle ekstatiese produksies kan sorg vir die wonderbaarlike bewyse van die ontwaakte pneuma wat volgens hulle die maatstaf vir ware apostelskap is. Hulle ware apostelskap is nie in menslike krag gegrond nie, maar in die goddelike pneuma wat in hulle aan die werk is (Schmithals 1969: 266-267).

Paulus is uitgedaag om hierop te reageer en baie onwillig kom hy tot die 'gesigte en openbarings van die Here' (2 Kor 12: 1). Daarmee wil hy aantoon dat ook hy die ekstases beheers. Maar dit bly vir hom 'n vreemde terrein sodat hy byvoeg dat hy nie op grond van sy groot openbarings beoordeel wil word nie, maar op grond van wat iemand 'my sien doen of my hoor se' ( 2 Kor 12: 6). En selfs wanneer Paulus die 'tekens van die apostel' in gnostiese terme beskryf, verstaan hy daaronder die wonderwerking van die woord: 'Die "tekens van die apostel" is met groot geduld onder julle verrig, deur tekens en wonders en kragtige dade' ( 2 Kor 12: 12; Schmithals 1969: 267-268). Paulus verkondig nie homself nie, nie sy pneuma nie, maar die woord, die goddelike genade wat van buite na die mens toe kom.

Die gnostiese aartsapostels het Paulus ook nog persoonlik probeer krenk deur hom daarvan te beskuldig, dat hy die kollekte wat vir die Jerusalemse gemeente ingesamel word, vir sy eie gewin wil gebruik. Paulus sou die skyn wek dat hy nie onderhoud van die gemeente ontvang nie, maar agteraf doen hy dit tog langs die omweg van die kollekte (Schmithals 1969: 266). In 2 Korintiërs 12: 16 verwys Paulus hierna: 'Nou word toegegee: ek het julle nie belas nie. Maar ek "agterbakse mens" sou julle "met listigheid" gevang het!'

Paulus was verniet so bekommerd oor sy posisie in die gemeente, want die gemeente het die beskuldigings teen hom nie geglo nie en end-uit by hom gestaan (Schmithals 1969: 100-101):

6 Maar God wat die vernederdes troos, het ons getroos deur die aankoms van Titus, 7 en nie net deur sy koms nie, maar ook deur die troos, waarmee hy by julle getroos is, en hy het ons vertel van julle begeerte om my te sien, hoe jammer julle is oor wat gebeur het, hoe julle vir my opkom sodat ek my oneindig kan verheug ( 2 Kor 7: 6-7).

Uit Paulus se opmerking 'omdat julle julle so beywer vir die Gees' (1 Kor 14: 12) lei Schmithals af dat vorms van ekstatiese vroomheid ' $n$ nuwigheid in die Korintiese gemeente was. In plaas daarvan dat hulle sulke liefhebbers van geestesopenbaringe moet wees, sou Paulus eerder wou sien dat hulle tevrede moet wees met die leer wat hulle, saam met al die ander gemeentes, ontvang het (Schmithals 1969: 269-270).

Agter die groot ywer vir die Gees staan die gnostici (Schmithals 1969: 268- 
270). Dit kom duidelik na vore in 1 Korintiërs 14: 37: 'Wie homself vir 'n profeet of pneumatikus hou, moet toegee dat ek aan julle niks anders as die gebod van die Here skrywe nie.' Die pneumatikus moet nie as 'n aparte kategorie anders as die profete beskou word nie. In Korinte het die gnostiese pneumatici as profete opgetree. Kragtens sy opgewekte pneuma is elke pneumatikus in staat om as profeet in die gemeente op te tree en die pneuma op te wek: 'Ontwaak, jy wat slaap, en staan op uit die dood' (Ef 5:14; Schmithals 1969: 261). Sulke profete wat vir sendingwerk uitgestuur word, is deur die gnostici apostels genoem.

Paulus lê die gnostici aan bande deur te benadruk dat die belang van die gemeente, die opbou daarvan, die maatstaf moet wees vir die rykdom van die Gees (1 Kor 14: 12). Hy onderskei tussen die spreek in tale waarby die spreker kontrole oor sy pneuma verloor en onverstaanbaar spreek en die profesie waar die profeet verstaanbaar spreek. Net verstaanbare uitings kan in die erediens toegelaat word. Schmithals (1969: 270) merk op dat Paulus hiermee die probleem nog net voorlopig opgelos het, want 'n gnostiese profeet kon ook heel verstaanbaar sy vervloeking 'vervloek is Jesus' uitspreek. Dat Paulus egter die Gees in Korinte wil demp, is onweerlegbaar want hy verduidelik dat die ekstatiese vroomheid nie die belangrikste is nie, maar dat alle geestesgawes ewe belangrik is. En om die punt nog verder tuis te bring skryf hy die liefde hoër aan as die spreek in tale en die profesie.

\section{PAUluS EN DIE historiese JESUS}

2 Korintiërs 5: 16 is 'n teks wat Bultmann altyd gereed gehou het vir sy verduideliking van die probleem van die historiese Jesus:

Gevolglik ken ons van nou af aan niemand meer na die vlees nie. Selfs as ons Christus na sy vlees geken het, ken ons Hom nou nie meer nie.

Bultmann het dit so uitgelê dat Paulus bewustelik nie die historiese Jesus wil ken nie. Paulus stel nie belang in Jesus se persoonlikheid nie, want dit sal 'n tweevoudige 'ken na die vlees' wees: Eerstens sal Christus net 'na die vlees', dit wil sê as 'n voorhande wêreldfenomeen, geken word en, tweedens sal so 'n ken ook net 'n vleeslike verstaan wees, dit wil sê 'n blote rekening hou met iets wat wêreldlik, voorhande en beskikbaar is (Bultmann 1972: 206-207). Nie Jesus se persoonlikheid of die woorde wat Hy sou gesê het, kan meer belangrik wees nie, want vir Paulus is Hy nie meer die verkondiger of boodskapper nie, Hy het die inhoud van die verkondiging, boodskap geword. Al wat nou saak maak is dat juis Hy die boodskapper van 
God is met die beslissende woord. Sy kruis, sy lot, is die beslissende heilsdaad van God (Bultmann 1972: 205). Sy kruis is nie bloot 'n afgehandelde gebeurtenis nie, dit kry gebeurekarakter, dit wil sê dit word verkondig as God se aanspraak op mense: My genade is vir jou genoeg (Bultmann 1972: 266). Deur die verkondiging van die kerk word verklaar dat hierdie onmessiaanse gekruisigde Jesus die Messias is. Hy is die Here wat kom.

Schmithals se ondersoek van die Pauliniese spraakgebruik het hom laat besef dat Paulus met 'Christus na die vlees' nêrens die historiese Jesus bedoel nie. Met 'Christus na die vlees' of 'Jesus' bedoel hy die aardse verskyning van die Veriosser, die 'dat' van sy bestaan. Hierdie 'dat' van sy bestaan sluit nie allerhande biografiese gegewens in nie, maar hou in dat Hy met sy wonde (Gal 6: 17) en met sy opstanding (Rom 8: 11) die inhoud en grond van die Christelike geloof is (Schmithals 1969: 124). Paulus beskryf dus met 'Christus na die vlees' juis die eskatologies gekwalifiseerde 'dat' van Jesus se bestaan wat vir Bultmann ook so belangrik is. Hierdie Christus ken Paulus. Nou, wil Schmithals weet, waarom sou Paulus van hierdie 'dat' sê, dat hy dit nie wil ken nie? Hoe sou Paulus dit kon regkry om te skryf: 'Gevolglik ken ons van nou af niemand meer na die vlees nie. Selfs as ons Christus na sy vlees geken het, ken ons Hom nou nie meer nie'?

Veral teen die agtergrond van Paulus se hewige stryd met die gnostiese dwaalleer is dit ook onmoontlik dat hy so 'n stelling sou maak. Teenoor hulle wat in ekstatiese vervoering kon uitroep: 'Vervloek is Jesus!' het hy beklemtoon dat hy Jesus as die gekruisigde verkondig. Van hierdie Jesus, wat na die vlees uit die geslag van Dawid stam (Rom 1: 3), wil hy nie afsien nie (Schmithals 1969: 294-295).

Die ongerymdheid tussen die Pauliniese teologie en die vers in 2 Korintiërs 5: 16 laat Schmithals 'n ander uitweg soek. Hy verklaar die vers as 'n gnostiese glosse. Die gnostiese invoeging sê dat niemand meer na sy natuurlike bestaan geken word nie, ook nie Christus nie. Die veragtelike liggaamlike gestalte, as woning van die pneuma, kry geen erkenning nie. 'Ons gnostici gee, sedert ons opname as pneumadeeltjies in die goddelike Pneuma-Christus, geen erkenning meer aan die natuurlike mens nie. Selfs as Paulus ons aan die gekruisigde Jesus bekend gestel het, gaan hy ons glad nie aan nie'.

Schmithals vertel dat Bultmann nie gelukkig was oor hierdie uitleg van die vers nie. Die feit dat Schmithals hierdie vers reeds in die manuskrip van sy proefskrif as 'n gnostiese glosse verklaar het, het Bultmann nie aangestaan nie. Bultmann het daarop aangedring dat Schmithals dit uit sy proefskrif moes uithaal, omdat dit vir die beoordeling van sy proefskrif nie onbelangrik sou wees nie. Schmithals het dit toe gedoen en dit eers afsonderlik gepubliseer, maar dit later as 'n aanhangsel by die gepubliseerde uitgawe van sy proefskrif ingesluit. 
Bultmann het Paulus se verhouding tot die historiese Jesus as 'n spesifieke teologiese standpunt van Paulus verstaan. En hierdie vers het vir hom gedien as die bewys van hierdie gevolgtrekking. Vir Schmithals was die betekenis van die vers in hierdie opsig ontsenu. Bultmann se houding en kritiek kon hom ook nie oortuig dat sy uitleg geen meriete het nie. En met sy nuut verworwe insig kon Schmithals nie meer aanvaar dat Paulus die baanbreker is of alleen is in sy verhouding tot die historiese Jesus nie. Dat Paulus nie in die 'hoe' van Jesus se lewe belang stel nie, maar in die 'dat' van sy lewe, onderskei hom nie van Petrus en Jakobus nie. Om die waarheid te sê, Paulus het dieselfde verhouding tot die historiese Jesus as wat die hele Nuwe Testament, behalwe die Sinoptiese Evangelies, het. Ons het hier nie met 'n spesifieke teologiese standpunt van Paulus te doen nie, maar Paulus gee blyke van 'n fundamentele tradisie waarin hy ook staan.

Schmithals het nie verskil van die fundamentele standpunt van Bultmann in verband met die historiese Jesus en die kerugmatiese Jesus nie. Schmithals het in werklikheid daarby gekom dat hy die basis waarop dit gerus het van Paulus af kon verbreed na die hele vroeëre Christendom toe. Die enigste stof wat nog weerstand gebied het teen die fundamentele Bultmannse standpunt was die Sinoptiese Evangelies wat nog belang het by die besonderhede van die aardse Jesus. Schmithals gaan dan ook op 'n stadium so ver om hierdie historiese Jesus-tradisie sowel as die Sinoptiese Evangelies apokrief te noem (Schmithals 1972: 49).

Met sy intreerede op 9 Mei 1962, getiteld 'Paulus und der 'historische' Jesus', aanvaar Schmithals dit as sy lewenstaak om oor die probleem van die historiese Jesus en die verkondigde Jesus na te dink (Schmithals 1972: 51). Ditt, van alles, is die teologiese vraagstuk by uitnemendheid.

\section{Literatuurverwysings}

BULTMANN, R 1954. Referat über die Dissertation des Pfarrers W. Schmithals 'Die Gnosis in Korinth'.

BULTMANN, R 1972. Glauben und Verstehen, Bd 1. Tübingen: Mohr.

SCHMITHALS, W 1969. Die Gnosis in Korinth: Eine Untersuchung zu den Korintherbriefen. 3. bearbeitete und ergänzte Aufl. Göttingen: Vandenhoeck. (FRLANT NF 48.)

SCHMITHALS, W 1972. Jesus Christus in der Verkündiging der Kirche: Aktuelle Beiträge zum notwendigen Streit um Jesus. Neukirchen-Vluyn: Neukirchener Verlag.

SCHMITHALS, W 1982. Auslegung von 1. Kon 2, 1-10, Protokoll der Tagung 'Alter Marburger', 2.-5. Jan. 1981 u. 4.-7. Jan 1982 in Hofgeismar, 68-82. 
SCHMITHALS, W 1984. Die Briefe des Paulus in ihrer ursprünglichen Form. Zürich: Evangelischer Verlag. (Zürcher Werkkommentare zur Bibel.) 